\title{
Regional Language Learning in Regional Multilingual Classes: Problems and Handling
}

\author{
Abdul Kadir ${ }^{1}$, Aziz Thaba ${ }^{2, *}$, Munirah $^{3}$, Sitti Aida Azis ${ }^{3}$, Rukayah $^{4}$ \\ ${ }^{1}$ Cokroaminoto College of Teacher Training and Education of Pinrang, Indonesia \\ ${ }^{2}$ Lembaga Swadaya Penelitian dan Pengembangan Pendidikan (LSP3) Matutu, Indonesia \\ ${ }^{3}$ Muhammadiyah University of Makassar, Indonesia \\ ${ }^{4}$ State University of Makassar, Indonesia
}

Received July 12, 2020; Revised August 14, 2020; Accepted September 17, 2020

\section{Cite This Paper in the following Citation Styles}

(a): [1] Abdul Kadir, Aziz Thaba, Munirah, Sitti Aida Azis, Rukayah, "Regional Language Learning in Regional Multilingual Classes: Problems and Handling," Universal Journal of Educational Research, Vol. 8, No. 11, pp. 5299 5304, 2020. DOI: 10.13189/ujer.2020.081130.

(b): Abdul Kadir, Aziz Thaba, Munirah, Sitti Aida Azis, Rukayah (2020). Regional Language Learning in Regional Multilingual Classes: Problems and Handling. Universal Journal of Educational Research, 8(11), 5299 - 5304. DOI: 10.13189/ujer.2020.081130.

Copyright $\bigcirc 2020$ by authors, all rights reserved. Authors agree that this article remains permanently open access under the terms of the Creative Commons Attribution License 4.0 International License

\begin{abstract}
Local languages are a part of the national education curriculum that is taught in schools. In its process, the curriculum of local language teaching and learning still faces various problems that hinder achieving the intended goals. One of the problems is the multicultural classroom. Teaching one particular local language in a multicultural classroom (Buginese, Javanese, Torajan, Makassarese, Mandarese, Bimanese, etc.) means dealing with several different local languages because different cultures will certainly have different local languages. The design of this research was a case study using a qualitative approach to understand the problems of language teaching in multicultural classrooms and formulate solutions for handling them. The results showed that, in this case, local language teaching and learning encountered various problems. The case study on the teaching of Makassarese language as a local language in Gowa, South Sulawesi at the primary school level indicated that it faced various problems in terms of process and goal achievement due to multicultural classroom conditions. The problems are included as follows. Firstly, the learning process does not go well due to limited classroom interactions. Secondly, the domination of the learning process occurs in the classroom by students with a culture that is in line with the local language being taught. Thirdly, the evaluation process is not balanced so that it creates an imbalance in the description of students' learning development. Based on these problems, the solution is by strengthening teachers'
\end{abstract}

understanding and perceptions in teaching on classroom dynamics and diversity, designing learning classroom management with balanced interactions, integrating learning processes between students using a collaborative model, and designing a balanced evaluation.

Keywords Teaching, Local Languages, Multicultural Classes, Learning Difficulties

\section{Introduction}

A local language is a form of Indonesian cultural wealth that should be preserved. This is because the onslaught of foreign cultures is increasingly powerful and capable of degrading the existence of the local language. One of the most appropriate ways to maintain the existence of the local language is through education (local language teaching in schools) [1]. Even though it is considered as the most appropriate strategy, local language teaching in schools still faces various challenges. Kern explained that all teaching process (in a classroom) can certainly have a problem, especially in language teaching [2]. It means there is no single teaching action that does not find obstacles or problems in the process or its results. However, Kern argued that each of these challenges can be overcome with certain strategies from the person handling the 
teaching and learning process. The same thing was also urged by Smit, Gijsel, Hotze, \& Bakker [3]. They are in line with Kern's view that the local language teaching in Indonesia is also faced with various problems. One of them is a problem due to pluralism or multicultural conditions in the classroom. Shee stated that teaching certain languages in multilingual classes is very difficult to do because various potential problems will arise if they are not accompanied by the ability to handle the classroom well [4].

Through this paper, a case of Makassarese language teaching and learning in elementary schools, especially in Gowa, South Sulawesi, is deliberately disclosed to understand the problems arising from multicultural conditions and concepts that can be used to address these problems. Understanding the problems and efforts to handle them is very urgent for the world of education in Indonesia because the orientation is on the progress of education and the preservation of local languages as the nation's cultural wealth.

\section{Literature Review}

Several theories such as; 2.1) learning a language; 2.2) language learning success; and c) multicultural classes in language teaching. Serve as a reference for reviewing research findings. The following is the explanation.

\subsection{Learn a Language}

Learning is essentially a mental process that leads humans to a certain meaning for themselves and their environment. It is also a cognitive process carried out by a person consciously and planned so that they transform from not knowing to know and from not understanding to understand [5]-[7]. As a process, learning is influenced by various factors, both those originating from within the learner and those originating outside the learner, i.e. environment [6], [8]. One of the environmental aspects that are often discussed regarding learning success is the classroom environment. Classroom in the traditional view is a place where learners receive knowledge from their teachers. Meanwhile, from a transformative perspective, the classroom is considered more flexible. It is not only a place for learners to receive knowledge from their teachers but more broadly as a vehicle for students to express themselves in the learning process [9], [10]. Therefore, to succeed in a learning process and achieve effective goals, it is very important to design good classroom management. It is a classroom that can facilitate students to learn [8]. The classroom is not just a rectangular space but all the aspects are involved in it. Furthermore, students and teachers are also parts of the classroom ecosystem.

The psychological view of learning behaviorism emphasizes that all forms of the response generated by students while learning are essentially the result of the stimulus they get [5]. The better the given stimulus is, the better the gained response will be. Stimulus in a learning process varies greatly starting from teaching materials, media, methods, teaching models, and interactions and communication between teachers and students. Moreover, the interaction between students is also part of the stimulus. In concerning the stimuli, a good classroom management design is also part of the learning motivation for students that can stimulate them to learn better.

Learning a language as a stimulus-response process can be observed from learners' language behavior. The learning process must be designed as a form of experience that occurs naturally. It also must be done programmatically and in various stages. The most important thing is that language teaching must be able to give the value of importance to learners in what they are learning so that it will reinforce them during the learning process.

\subsection{Language Learning Success}

Traditionally, the success of language learning is seen from the values obtained by learners. Here, the learning process is not a consideration for teachers in assessing learning success. Meanwhile, in modern transformative views, the success of language learning is a complex component. It is not only the value obtained. The whole series of processes that learners go through in the process of learning are indicators that can be used as benchmarks to assess learning success [11]. The success of learning a language is determined by various factors, both those originating from within the learner (such as motivation and interest in learning) and those originating outside the learner (such as the environment) [6], [8].

Teaching a language in a certain class will never be separated from problems [2]. This is because teaching a language in one class means facing various heads (IQ) and different characters. Some learners have IQ and learning character that support the learning process well. However, some of them have IQ and learning characters that require special treatment. This kind of dynamic is a challenge and hard work that a teacher must go through. The hope is one. It is how each student can learn well and get good results without having to give unequal treatment due to differences in IQ and learning character [1], [12], [13].

\subsection{Multicultural Classes in Language Teaching}

Indonesia as a pluralistic country with a high level of cultural mobility provides a new color and dynamic in the world of education. For example, a classroom can consist of various cultures (Buginese, Mandarese, Balinese, Javanese, Sundanese, etc.) with their respective mother tongue (L1). Cultural diversity in a classroom can be seen from two sides. The first is from the positive side where this diversity can make it easier for students to understand 
the existence of themselves and others so that it can have the opportunity to provide moral education. Meanwhile, the second is the negative side where it provides a certain gap or opportunity for the domination of learning to occur over a certain culture if the language learned is a certain language. In addition, the learning process will support limited class interactions. Furthermore, there also will be an unbalanced evaluation process resulting in an imbalance in the description of children's learning development [4], [12], [14].

\section{Research Methods}

The design of this research was a descriptive study because the researchers will clearly describe the classroom interactions that occur in the local language learning process in local multilingual classrooms. In this study, the type of reality was multiple, holistic, based on construction, and based on understanding [15]. Therefore, the results obtained in this study could be different from other researchers when examining the same object. The approach used in this study is qualitative. It is a study approach that involves social phenomena, not in the form of numbers which are used as the basic reference for drawing conclusions. To understand classroom interactions in the local language teaching in local multilingual classrooms, researchers used the Flanders' Interaction Analysis Categories (FIAC) method [16]. It consists of ten categories. Seven categories are used to categorize various aspects of what the teacher says, two categories are used to categorize what students say, and the one last category is used when the class becomes quiet or noisy. The data in this study were all forms of classroom interactions that occur in the teaching and learning process. Therefore, the forms of data in this study were the result of observations.
Related to this, the data sources in this study were teachers and students.

The employed instrument in this study was the researchers themselves (key instruments). Furthermore, there are three data collection techniques applied in this study, i.e. literature study, observation using recording tools, and note-taking. Qualitative data analysis was carried out interactively and continuously until it was considered completed. Therefore, the data became saturated. The measure of data saturation was indicated by no longer obtaining new data or information. The data analysis included data reduction, data display, and conclusion drawing/verification [15], [17], [18].

\section{Discussion Findings}

There are many interesting facts about language teaching, especially local languages. The following is a presentation of research findings and discussions related to regional language learning in regional multilingual classes. These findings explain the problems and efforts to overcome them

\subsection{Limited Class Interaction Problems}

Observations conducted in Makassarese language teaching process as a local language that involved several cultures indicated a problem in which the classroom interactions that occurred were very limited. Teachers dominated the class more, as do students with cultural backgrounds that were in line with the local language being taught. Therefore, students with different cultural backgrounds became more passive and only acted as listeners or note-taker of the subject matter. The results of these observations are presented in the following table.

Table 1. Observation Result with Flanders' Interaction Analysis Categories (FIAC) Method

\begin{tabular}{|c|c|c|c|c|c|c|c|c|c|c|c|}
\hline \multirow{2}{*}{ No } & \multirow{2}{*}{$\begin{array}{l}\text { School/ } \\
\text { Class }\end{array}$} & \multicolumn{10}{|c|}{ Aspects of Interaction Observed with Percentage of Success (0-100\%) } \\
\hline & & 1 & 2 & 3 & 4 & 5 & 6 & 7 & 8 & 9 & 10 \\
\hline 1 & 01 & 30 & 50 & 10 & 60 & 60 & 40 & 40 & 30 & 20 & 40 \\
\hline 2 & 02 & 20 & 40 & 20 & 40 & 60 & 40 & 30 & 40 & 30 & 30 \\
\hline 3 & 03 & 40 & 40 & 30 & 60 & 60 & 40 & 40 & 40 & 40 & 40 \\
\hline 4 & 04 & 20 & 30 & 20 & 40 & 40 & 30 & 50 & 30 & 30 & 20 \\
\hline
\end{tabular}




\section{Information:}

Aspect:

(1) Acceptance, (2) Praise (trigger), (3) Use students' ideas, (4) Ask questions, (5) Teach, (6) Direct, (7) Right to criticize, (8) Student responses, (9) Student initiatives, (10) Silence or Crowds.

Score Criteria: Very good (80-100), Good (60-79), Good enough (40-59), Not good (20-39), Not good or bad (0-19)

Referring to the ten categories of classroom interaction put forward by Flanders, the results of the observations showed that the Makassarese language learning process in the multicultural class was not going well. This is because almost all of the evaluated interaction categories do not meet the standards. This means that classroom interactions that occur during the learning process have serious problems. Learners from different language cultures get a barrier to the learning process because they do not understand the language being taught. This is different for learners from Makassarese language culture. They clearly understand and easily master the learning material and its instruction language. Therefore, the opportunity for the interaction given to students from Makassarese language culture is very broad than that to students from different language cultures.

Apart from the reasons for differences in language culture, the problem of limited classroom interaction in Makassarese language teaching is also caused by several things. Firstly, the teacher dominantly uses Makassarese language as the instruction language. Second, the teaching materials used are not for the multilingual classroom. Therefore, it is important to note that local language teaching in multicultural classrooms is a complex teaching process. The teacher must understand that the classroom is in multiple conditions. They must be able to use teaching strategies that can provoke comprehensive classroom interactions. They must also be able to play a balanced role such as managing the class well and using multilingual instruction (Makassarese - Indonesian). Furthermore, the teaching materials used must also pay attention to the diversity of students' language culture so that it must also be multilingual.

This problem is often encountered in an L2 learning process. Yumru revealed that teaching L2 to strong L1 classes will face significant challenges [19]. It is because the strength of the L1 still affects the learning process [20][22]. Likewise in Makassarese language learning, students with different language cultures certainly make Makassarese language as their L2 in addition to the strength and pressure of L1 in the learning process.

\subsection{Class Domination Problems}

The observation data from Makassarese language teaching in Gowa Regency in a multicultural classroom proves that there is classroom domination by students with Makassarese culture in all schools that become the observation locations. The observation data are shown as follows.

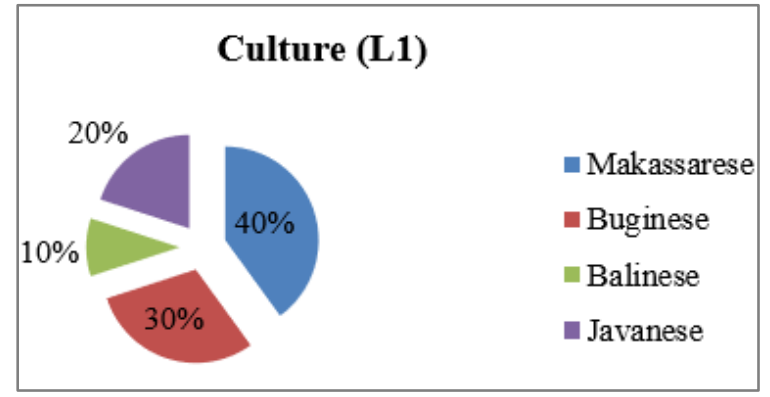

Figure 1. Percentage of Class Domination in Location 01

The figure above shows the percentage of domination distribution in the classroom during the Makassarese language teaching process in location 01. It indicates that Makassarese culture occupies the highest domination by $40 \%$, followed by Buginese culture by $30 \%$, Javanese culture by $20 \%$, and Balinese culture by $10 \%$. From the data above, it indicates that students with Makassarese culture dominate the classroom during the learning process.

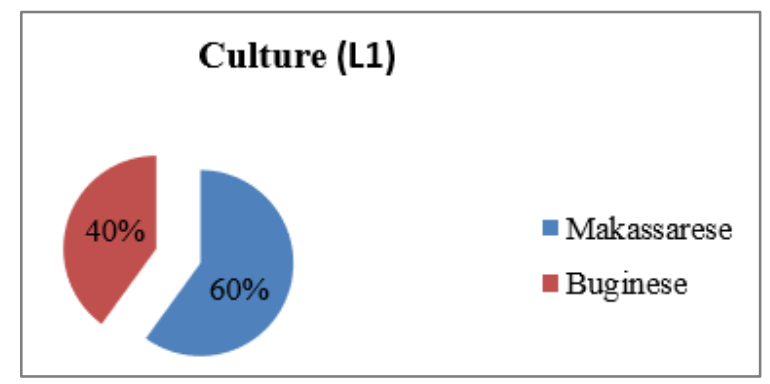

Figure 2. Percentage of Class Domination at Location 02

The figure above shows the percentage of domination distribution in the classroom during the Makassarese language teaching process in location 02. It indicates that Makassarese culture occupies the highest domination by $60 \%$, followed by Buginese culture by $40 \%$. From the data above, it indicates that students with Makassarese culture dominate the classroom during the learning process. 


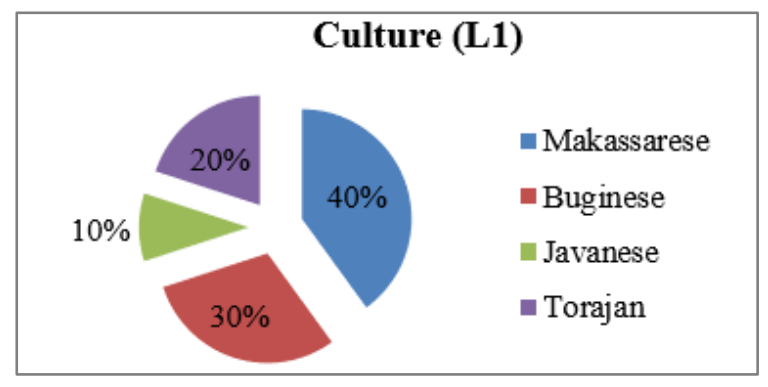

Figure 3. Percentage of Class Domination at Location 03

The figure above shows the percentage of domination distribution in the classroom during the Makassarese language teaching process in location 03. It indicates that Makassarese culture occupies the highest domination by $40 \%$, followed by Buginese culture by $30 \%$, Torajan culture by $20 \%$, and Javanese culture by $10 \%$. From the data above, it indicates that students with Makassarese culture dominate the classroom during the learning process.

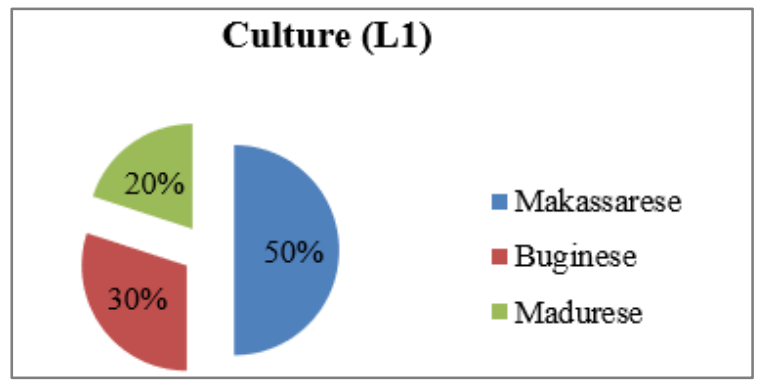

Figure 4. Percentage of Class Domination at Location 04

The figure above shows the percentage of domination distribution in the classroom during the Makassarese language teaching process in location 04. It indicates that Makassarese culture occupies the highest domination by $50 \%$, followed by Buginese culture by $30 \%$, and Madurese culture by $20 \%$. From the data above, it indicates that students with Makassarese culture dominate the classroom during the learning process.

Based on the data shown from the four graphics of the percentage of classroom domination above, it proves that in Makassarese language teaching process as a local language in Gowa Regency between students with Makassarese, Buginese, Balinese, Javanese, Torajan, and Madurese language cultures, students from Makassarese language culture dominate the classroom. Because of this dominance, it is clear that learners with different language cultures will experience being excluded and tend to form certain groups. The groups in the classroom, based on these findings, are different from the study group in the cooperative approach. The referred group is more about the aspect of social identity that builds a barrier within the learners during the learning process. This is certainly a problem because a classroom is considered a limited social organization that must be built based on differences but upholds common goals and interests. If the goals and interests create a separator, it can be confirmed that the learning process is in an unbalanced condition so that the results of the learning process will be poor [23]-[25].

Based on these cases or problems, Taylor [9], Mezirow [11], Goldie [26] explained that these must be solved by conducting integration or collaboration in the learning process. Social blocks or groups that are formed and cause different perceptions, goals, and interests of a learning process as an organization must be able to be overcome. This task is very important for a teacher because students do not yet have awareness of their existence as a part of a classroom organization which should have the same perceptions, goals, and interests.

\subsection{Unbalanced Evaluation Problems}

To understand the classroom as a learning organization, it must be accompanied by an understanding that classroom citizens are different individuals, both in terms of their traits, attitudes, characters, and even cognitive powers [27]. Therefore, the evaluation that is carried out must also give a different tendency. In terms of Makassarese language teaching as a local language in multicultural classrooms, the teacher must be able to provide evaluations with different portions. For example, when the teacher assesses students' understanding regarding the meaning of a word, then the results will show that students with Makassarese language culture will get a perfect score, while students with Javanese, Madurese, Balinese, Buginese, or Torajan language culture will only get a score of around six or not a perfect score. It is because the identity and abilities of each learner are different. Teachers should not generalize that students with a score of six have a poor level of knowledge, while those with a perfect score (e.g., 10) have a perfect or a high level of knowledge. This is because it is natural for students with the Makassarese language culture to understand the meaning of a word being evaluated since it is their language. Therefore, they can easily understand the meaning of the word. It is different for learners with Javanese, Sundanese, Balinese, Torajan, and Madurese language cultures in which Makassarese language is their L2. Consequently, describing the results of the evaluation must be based on the proportion that they are beginners or L2 learners and cannot be generalized with L1 learners.

\section{Conclusions}

Makassarese language teaching as a local language in Gowa Regency faces a situation in which students are in a multicultural condition. The cultures include Makassarese, Buginese, Javanese, Torajan, Madurese, and Balinese. Due to these conditions, the teaching and learning process of the Makassarese language faces several serious problems. The problems included as follows. Firstly, the learning process does not go well due to limited classroom interactions. Secondly, the domination of the learning process occurs in 
the classroom by students with a culture that is in line with the local language being taught. Thirdly, the evaluation process is not balanced so that it creates an imbalance in the description of students' learning development. Based on these problems, the solution is by strengthening teachers' understanding and perceptions in teaching on classroom dynamics and diversity, designing learning classroom management with balanced interactions, integrating learning processes between students using a collaborative model, and designing a balanced evaluation.

\section{REFERENCES}

[1] E. Rustan, "Pembelajaran Bahasa dan Sastra Daerah Berbasis Multikultural dalam Mewujudkan Pendidikan yang Berkarakter di Era Globalisasi,” in International Seminar Language Maintenance and Shift, 2011.

[2] R. Kern, Literacy and language teaching. Oxford University Press, 2000.

[3] J. Smit, M. Gijsel, A. Hotze, dan A. Bakker, "Scaffolding primary teachers in designing and enacting language-oriented science lessons: Is handing over to independence a fata morgana?,” Learn. Cult. Soc. Interact., vol. 18, hal. 72-85, 2018.

[4] N. K. Shee, "Karen Education Department's multilingual education for language maintenance,” Kasetsart J. Soc. Sci., 2018.

[5] L. B. Baruque dan R. N. Melo, "Learning theory and instruction design using learning objects,” J. Educ. Multimed. Hypermedia, vol. 13, no. 4, hal. 343-370, 2004.

[6] L. Harasim, Learning theory and online technologies. Routledge, 2017.

[7] W. Khuanwang, N. Lawthong, dan S. Suwanmonkha, "Development of Evaluation Standards for Professional Experiential Training of Student Teachers,” Procedia - Soc. Behav. Sci., vol. 217, hal. 878-886, 2016.

[8] D. A. Kolb, R. E. Boyatzis, dan C. Mainemelis, "Experiential learning theory: Previous research and new directions," Perspect. thinking, Learn. Cogn. styles, vol. 1, no. 8, hal. 227-247, 2001.

[9] E. W. Taylor, "Transformative learning theory," in Transformative learning meets bildung, Brill Sense, 2017, hal. 17-29.

[10] M. Vidyasagar, A theory of learning and generalization. Springer-Verlag, 2002.

[11] J. Mezirow, Learning as Transformation: Critical Perspectives on a Theory in Progress. The Jossey-Bass Higher and Adult Education Series. ERIC, 2000.

[12] D. Van Le, J. Montgomery, K. C. Kirkby, dan J. Scanlan, "Risk prediction using natural language processing of electronic mental health records in an inpatient forensic psychiatry setting,” J. Biomed. Inform., vol. 86, hal. 49-58, 2018.
[13] F. Mahmoudi dan Y. Özkan, "Exploring Experienced and Novice Teachers' Perceptions about Professional Development Activities,” Procedia - Soc. Behav. Sci., vol. 199, hal. 57-64, 2015.

[14] J. S. Kahn, Culture, multiculture, postculture. Sage London, 1995.

[15] C. Glesne, Becoming qualitative researchers: An introduction. ERIC, 2016.

[16] V. O. Amatari, "The instructional process: a review of Flanders' interaction analysis in a classroom setting,” Int. $J$. Second. Educ., vol. 3, no. 5, hal. 43-49, 2015.

[17] M. C. Hoepfl, “Choosing qualitative research: A primer for technology education researchers," Vol. 9 Issue 1 (fall 1997), 1997.

[18] V. Dickson-Swift, E. L. James, S. Kippen, dan P. Liamputtong, "Doing sensitive research: what challenges do qualitative researchers face?,” Qual. Res., vol. 7, no. 3, hal. 327-353, 2007.

[19] H. Yumru, "EFL Teachers' Preferences for Teacher Learning Activities in a Professional Development Course," Procedia - Soc. Behav. Sci., vol. 199, hal. 178-183, 2015.

[20] S. Deb, Suraksha, dan P. Bhattacharya, “Augmented Sign Language Modeling(ASLM) with interaction design on smartphone - an assistive learning and communication tool for inclusive classroom,” Procedia Comput. Sci., vol. 125, hal. 492-500, 2018.

[21] A. Z. Sak dan A. Saka, "Student teachers' views about effects of school practice on development of their professional skills,” Procedia - Soc. Behav. Sci., vol. 1, no. 1, hal. 1597-1604, 2009.

[22] D. M. Early, K. L. Maxwell, B. D. Ponder, dan Y. Pan, "Improving teacher-child interactions: A randomized controlled trial of Making the Most of Classroom Interactions and My Teaching Partner professional development models,” Early Child. Res. Q., vol. 38, hal. 57-70, 2017.

[23] U. Hasson, G. Egidi, M. Marelli, dan R. M. Willems, "Grounding the neurobiology of language in first principles: The necessity of non-language-centric explanations for language comprehension,” Cognition, vol. 180, hal. 135157, 2018.

[24] M. A. Weegar dan D. Pacis, “A Comparison of two theories of learning-behaviorism and constructivism as applied to face-to-face and online learning," in Proceedings e-leader conference, Manila, 2012.

[25] O. J. Solheim, M. Rege, dan E. McTigue, "Study protocol: 'Two Teachers': A randomized controlled trial investigating individual and complementary effects of teacher-student ratio in literacy instruction and professional development for teachers,” Int. J. Educ. Res., vol. 86, hal. 122-130, 2017.

[26] J. G. S. Goldie, "Connectivism: A knowledge learning theory for the digital age?,” Med. Teach., vol. 38, no. 10, hal. 1064-1069, 2016.

[27] A. M. Sardiman, Interaksi \& motivasi belajar mengajar. Rajagrafindo persada (rajawali pers), 2004. 